IRSH 46 (200I), Supplement, pp. 79-106 DOI: I0.1017/S0020859001000293

(C) 200 I Internationaal Instituut voor Sociale Geschiedenis

\title{
Officially Solicited Petitions: The Cabiers de Doléances as a Historical Source
}

\author{
GilBERT SHAPIROAND JOHN MARKOFF
}

\section{INTRODUCTION: THE CAHIERS DE DOLÉANCES}

The cabiers de doléances of 1789 have generally been regarded as unique historical documents. In convening the Estates General, the royal government followed centuries-old precedent in asking the nation not only to elect representatives to an assembly, but to provide them with lists of the demands, wishes, and grievances of their constituents as well. One could hardly describe these documents as resources unknown to historians. Apart from a very few who have seen these documents essentially as fraudulent, ${ }^{\mathrm{I}}$ historians have generally seen them as uniquely vox populi. Tocqueville, for example, described them as "an authentic account" of the ideas and feelings of the nation drawn up "in perfect freedom". More recently, Guy Chaussinand-Nogaret saw them as "the truest sampling of opinion ever realized in the France of the Old Regime". ${ }^{2}$

The procedures by which deputies were selected to represent the clergy, nobility, and commoners at the Estates General of I789 were quite complex, and differed for the three estates. In most of France, rural communities met in face-to-face assemblies to elect their delegates to a higher assembly, the assembly of the commoners - the third estate - of the basic electoral circumscription, the bailliage. There they met with town delegates chosen at a town assembly, who, in many towns, were themselves elected by the town's corporate groupings, such as its guilds and professional bodies. The bailliage assembly often chose delegates for the Estates General; sometimes, however, it sent its delegates to an assembly composed of the representatives of several bailliages and it was this latter "bailliage cluster" that deputed to Versailles. ${ }^{3}$

For the nobility the process was far simpler; eligible nobles met in the main town of the bailliage or bailliage cluster at the same time as the

I. Notably Augustin Cochin, "Comment furent élus les députés aux États Généraux?", ch. 5 in idem, Les Sociétés de Pensée et la Démocratie Moderne (Paris, 1924), pp. 209-232.

2. Alexis de Tocqueville, The Old Regime and the French Revolution, trans. Stuart Gilbert (Garden City, NY, 1955), p. 262; G. Chaussinand-Nogaret, La noblesse au XVIIIe siècle: de la féodalité aux lumières (Brussels, I984), p. I8 I.

3. We have coined the term "bailliage cluster" as an English equivalent of the rather clumsy French phrase, "bailliage principal avec secondaires" used by Hyslop and Brette. 
highest stage meeting of the third estate, and elected delegates to the Estates General. (Even the nobles' procedures were not devoid of complexity: Paris had an aberrant two-stage process and women nobles with fiefs could choose a male delegate to represent them, making the small permitted female noble participation multistep.) For the clergy, parish priests could be represented either in person or through a delegate at the corresponding meeting of the bailliage or bailliage cluster, and ecclesiastical corporate bodies (chapters, monasteries, nunneries) could choose delegates. All of the assemblies just mentioned (and some of the individual participants in some stages) had the right to draw up a list of grievances, a cabier de doléances, and many did so.

Several characteristics of the cabiers, especially when considered together, have made their use by historians of France extremely common.

(I) They are very numerous. Some 40,000 rural communities drew up cabiers; so did many towns and, within the towns, urban corporations (such as guilds); so did hundreds of assemblies of France's upper strata - its clergy, its nobility, and its urban commoner elite.

(2) They are accessible. As quasi-sacred texts from the founding crisis of modern France, very many have been published in finely edited official editions. Graduate students learning French revolutionary history are likely to be exposed to them in seminars around the world, even if they never get the funds to travel to France, where many other cabiers await them in the archives.

(3) They are in a fairly standard format. The national regulations spelling out the electoral process in considerable detail helped impart a standardized structure to the crafting of these documents, as did a familiar culture of legal document forms. This standardization was powerfully reinforced by an energetic campaign by the many parties who sought to influence the documents by circulating models. This campaign reached out into the depths of the countryside. A startled official in Provence lamented the effort of the urban notables of Sisteron to "address the peasants and workers in their usual language in order to get them to take an interest in present affairs"; ${ }^{4}$ the nobility of Brittany made their case for peasant support against King and urban elites in Breton.' All over France, people had broadly similar notions of what a cabier ought to look like. The achievement of a common culture of cabier-writing makes one confident that differences among cabiers may be attributed to differences in the social composition of the assemblies that wrote them, as well as differences in the economic, social, and political challenges across the map of France, rather than differences in understanding

4. Quoted in Monique Cubells, Les horizons de la liberté: La naissance de la Révolution en Provence, $1787-1789$ (Aix-en-Provence, 1987), p. 68.

5. Roger Dupuy, De la Révolution à la Chouannerie: paysans en Bretagne, $1788-1794$ (Paris, I988), pp. 24-32. 
what a cabier was. There were some important differences, however, concerning the degree to which a cabier was intended to control the delegate who carried it, an important matter which we discuss below.

(4) They cover almost the entire map of France. With few significant lacunae, peasant communities, clergy, urban notables, and nobles drew up cabiers throughout the country. A very small number were produced by such aberrant procedures as to make the comparability of their contents with those of the overwhelming majority difficult; for example, the Provincial Estates of Dauphiné, Béarn and Navarre were permitted to choose delegates and write their own cabiers. ${ }^{6}$ The nobility of Brittany refused to participate altogether. Some guilds in some towns did not write the cabiers they were permitted - but probably almost every rural community did so. ${ }^{7}$ Parish priests, allowed to bring their personal cabiers to the bailliage assembly of the clergy, often seem not to have done so. And the fortunes of document loss mean that significant numbers of cabiers have not survived. Nonetheless, there is a very large proportion of the general cabiers of the clergy, nobility, and third estate available to historians; there is also a very large number of the parish cabiers extant, from which it is possible to draw a representative national sample of parish cabiers. Towns in many parts of the country have surviving cabiers from their corporations. Other cabiers have been less wellcatalogued, and therefore their sampling characteristics are far less clear.

(5) They are almost simultaneous. The overwhelming majority of the tens of thousands of documents were drawn up within a few weeks of one another in the spring of 1789 , providing an unrivalled snapshot of the views of the nation.

(6) The assemblies drawing up the cabiers can be identified with major social groupings. Because the documents emerged as an integral part of the electoral process, that process provides convenient, and very meaningful, social labels for those who adopted each cabier. They come to the historian readily identified with a rural community, an urban guild, a parish priest, local nobility. While much debate continues over just which peasants, or nobles, or clergy are those whose views prevailed in particular assemblies, and whose voices we therefore encounter in these documents, broad contrasts of different social categories, or of similar social categories in different parts of the country, are extremely easy to extract from these sources. Researchers who wish to know how the complaints of villagers in one part of France differed from those in another, or on what subjects nobles and commoner elites agreed, and on what they differed, will be almost certain to consult

6. Beatrice Hyslop, A Guide to the General Cahiers of 1789 with the Texts of Unedited Cabiers (New York, I968), ch. I.

7. Gilbert Shapiro and John Markoff, Revolutionary Demands. A Content Analysis of the Cahiers de Doléances of 1789 (Stanford, CA, I998), pp. 233-235; Gilbert Shapiro, John Markoff, and Silvio Duncan Baretta, "The Selective Transmission of Historical Documents: The Case of the Parish Cabiers of 1789", Histoire et Mesure, 2 (1987), pp. I I 5-I72, I I9-I 20. 
relevant cabiers. But social categories that had no distinct assemblies in the convocation process (for example, protestants), as well as social categories whose members were largely excluded from participation at any of the assemblies (for example, women) cannot be studied in this way.

(7) The writing of the cabiers occurred at the beginning of one of the world's great social upheavals. Had there been no French Revolution, the snapshot of views on a national scale of a large and varied early modern European society would still be an unrivalled source of data. Had there been only a haphazard and unstandardized collection of a large number of miscellaneous petitions at the beginning of such a great social upheaval, nevertheless those petitions would be minutely scoured for what they reveal of the social forces generating such a momentous event. But the combination of a nationally standardized and readily accessible collection of documents from identifiable and significant social categories at the onset of the great upheaval makes the cabiers virtually irresistible to students of French revolutionary history.

But if the cabiers are a widely used resource for social history they have not always been a wisely used resource. The potential for systematic comparison could be realized only if pursued following rational sampling principles and a content analysis featuring a comprehensive coding scheme. Our recent effort to meet these requirements will be drawn upon and cited repeatedly below. The sample consists of 748 rural parishes (clustered in 46 bailliages), the 166 extant cabiers of the nobility, and 198 documents, virtually all of the extant "general cabiers" of the third estate (those drawn up in the final stage of the convocation and actually carried to Versailles). The database holds over 27,000 grievances expressed in the documents of the nobility, over 47,000 grievances in the documents of the third estate, and over 28,000 grievances in those of the rural parishes.

These 100,000 grievances are recorded in a code which reflects the semantic structure of a grievance: a designation of the subject of the grievance (ordinarily an institution or problem area, such as the church's finances, or the salt tax); a code for the predicate, which consists of the action demanded (for example, the abolition or reform of the subject), and an optional object, which is sometimes required to complete the meaning of the demand; and a code for any qualifications, such as: COND, a conditional demand; ALT, an alternative possible action; LO, a demand addressed to local conditions; or PV, one addressed to provincial conditions. The code has I,227 institutional subjects (organized in a four-level hierarchy), 9I standard actions 76 standard objects and 45 code categories to deal with qualifications. ${ }^{8}$ 


\section{THE CAHIERS VIEWED AS PETITIONS}

While the combination of characteristics itemized above is unique, we propose to view the cabiers here as "petitions", thereby enabling us to gain insights from comparisons with other petitions, including other petitions in the early modern world. While a petition is always a statement of wishes addressed to some authority, the character of that authority and the relationship of the petitioners to that authority are subject to great variation. To properly appreciate the sort of petitions represented by the cabiers of 1789 , we need to focus on three critical dimensions of petitions in the abstract:

(I) the circumstances of a petition's origin;

(2) the manner of a petition's composition; and

(3) the role of the petition-bearer.

\section{The circumstances of a petition's origin}

First, we must consider the circumstances in which a petition comes into existence. Petitions from below may be strictly forbidden, intermittently accepted, generally permitted, plainly encouraged, or even demanded from on high. We see this as a continuum of increasing openness of those on high to public expressions of the wishes of those below. From the point of view of the freedom for autonomous action of those down below, however, matters are far more complex than such a simple linear progression, for it is in the intermediary zone, where petitioning is generally permitted, but not encouraged, let alone demanded from above, that the act of petitioning may be seen to be most autonomous. It is probably the case as a general sociological proposition, however, that whenever some right to petition becomes widely recognized, some in positions of power will discover that it is in their interest to sponsor petitions. Such solicited petitions, addressed to other power-holders, may be a significant means of exerting pressure on rivals; addressed to oneself they may constitute a resource in intra-elite debates, as when Members of Parliament in the English revolution discovered the power of evidence that "the People" were demanding something of them. Parliament "drew up petitions to itself", as one satirist put it. ${ }^{9}$

As petitions, the cabiers are toward the high end of this continuum, well beyond the halfway point between state encouragement and state insistence. Their significance must be assessed against the background of severe limitations on the right to petition in Old-Regime France. The absolutist state provided no general right of assembly, no general right to 
debate official actions, and a vigorous, if porous, censorship apparatus. ${ }^{10}$ Not only were the cabiers a unique opportunity for the public expression of positions, a privilege not normally enjoyed even by the nobility, but the convocation regulations literally mandated that certain assemblies must provide their delegates with cabiers. Article 25 of the basic regulation is unambiguous: "The parishes and communities [...] shall assemble $[\ldots]$ to join in drawing up of cabiers and nominating deputies". ${ }^{\text {II }}$ We think it noteworthy that France's rural communities, required by the convocation regulations to produce cabiers, probably were nearly unanimous in writing these documents. ${ }^{\mathrm{I}}$ We might well wonder what happened if a rural community opted, intentionally or inadvertently, to send off its delegates with no cabier. At one Norman bailliage assembly, a few rural delegates did show up without these documents, according to the records of the proceedings - but, nevertheless, we actually have cabiers from those parishes. It seems very likely that someone told those delegates after they arrived to get, or make, a proper cabier - unless they realized on their own that they ought to do so. ${ }^{13}$

The town assemblies that chose deputies for the bailliage meeting of the third estate, as well as the bailliage assemblies of the clergy, nobility, and third estate that chose deputies to the Estates General were also required to provide those deputies with cabiers. ${ }^{14}$ High up in the electoral scheme, few assemblies with the right to send cabiers and delegates to Versailles failed to so. The major exception was the nobility of Brittany, who, as we stated above, boycotted the proceedings.

Other participants were permitted but not required by the official rules to write cabiers (for example, ecclesiastical corporations sending deputies to the bailliage assembly of the clergy, or parish priests attending in person). For still others, most importantly the urban corporations, nothing very specific is said at all. Preliminary cabiers of the clergy and guild cabiers were often not written, ${ }^{15}$ although an absence of any thorough

I0. Robert Darnton, The Literary Underground of the Old Regime (Cambridge, MA, I982) and The Business of Enlightenment: A Publishing History of the Encyclopedia (Cambridge, MA, I979); Daniel Roche, "Censorship and the Publishing Industry", in Robert Darnton and Daniel Roche (eds), Revolution in Print: The Press in France, I775-1800 (Berkeley, CA [etc.], I989), pp. 3-26.

I I. Jacques Cadart, "Règlement fait par le Roi pour l'exécution des lettres de convocation", in idem, Le régime électoral des Etats Généraux de 1789 et ses origines (1302-1614) (Paris, 1952), p. 197.

I2. See note 7 .

I3. Emile Bridrey, Cabiers de doléances du bailliage de Cotentin (Coutances et secondaires) pour les Etats généraux de 1789 (Paris, 1907), pp. I I-I 2, 28-30.

I4. Cadart, "Règlement", arts 25, 28, 33, 40, 43-45, pp. 197-199.

I 5 . Charles Porée, Cabiers des curés et des communautées ecclésiastiques du bailliage d'Auxerre pour les Etats généraux de 1789 (Auxerre, 1927), pp. 2ff.; Philip Dawson, Provincial Magistrates and Revolutionary Politics in France 1789-1795 (Cambridge, MA, 1972), pp. I 50-I I. 
inventory of these types of document makes it impossible to be terribly confident about the precise proportions. There are no known surviving documents from urban corporate groups in seven-eighths of the towns where such groups were required to meet. ${ }^{16}$

\section{The manner of a petition's composition}

Second, the manner of a petition's composition, including the recruitment of petitioners and the contents of the petition may be unregulated by the state, arrived at by tacit understandings of the permissible, or formally governed by official regulation. In the more democratic states at the beginning of the twenty-first century, petitioning is rather close to the unregulated end of this particular continuum. Pretty much anyone may decide to circulate a petition or sign one circulated by others; and the petitioners are free to put almost anything they wish into their petition, perhaps occasionally restrained by libel laws. The cabiers were towards the opposite extreme in regard to who might petition, although not in regard to content; only definite groups were permitted to submit them, but their contents were extremely free. The government announced in richly complex detail how the tens of thousands of assemblies drawing up cabiers were to be constituted, who would have the right to attend which meetings, who would preside over each meeting, with very different rules for who chaired, say, a meeting of clergy and who chaired a village assembly, and how decisions were to be made. The initial announcement was followed by a long series of decisions that accepted, or - far more often - rejected claims by various groups to deviate from the modal pattern, usually by writing their own cabier. (The government agreed, for example, to permit the provincial estates of Béarn, Navarre, and Dauphiné to draw up cabiers, but refused to allow other provincial estates to do so.)

Unlike the close regulation of participation and procedures, the contents of the cabiers were not officially dictated. Indeed, there was some effort to keep government officials from overtly injecting themselves into the debates of the assemblies. The basic regulation barred most officials from any such effort. ${ }^{17}$ Those who did have a role in convening local assemblies, and in presiding over meetings, varied somewhat in the degree to which they saw themselves as permitted to advocate any particular content for the cabiers. ${ }^{18}$

Against a background in which getting around the police and the censorship was a well-honed art, however, we may be confident that there were tacit understandings about what ought not to be said and how things

16. Dawson, Provincial Magistrates, p. I5 I, n. 37.

17. Cadart, "Règlement", arts 8, 30.

I8. Hyslop, Guide, pp. 53-55. 
ought to be phrased. We may be skeptical about whether all those who agreed to cahiers praising the King's many virtues believed their own words. ${ }^{19}$ But we may be quite certain that to the extent that there was antimonarchical sentiment, the cabiers were not the place to express it. The noble deputy Count Beugnot, whose memoirs have a number of interesting observations on the drafting of the cabiers of his bailliage, quotes a very exceptional parish cabier that he turned over to the relevant authorities for criminal prosecution: "We give our deputies power to ask the lord-King's consent to the preceding demands; and should he grant it, to thank him, but should he refuse, to unking him". ${ }^{20}$ (If this document really existed, we have not been able to find it.)

But while some things may have been virtually impossible to get into the cabiers, we also need to realize that assemblies were often willing to defy authorities. The rules required many parish assemblies to be chaired by a seigneurial judge. Although some historians have contended that the mandated presence of such a judge as chair must have inhibited the peasants from expressing their views of the seigneurial regime, we find evidence that complaints about seigneurial rights were just as numerous and just as strong when a seigneurial judge presided as when he did not. ${ }^{2 \mathrm{I}}$

The royal invitation to participate was virtually a wide-open invitation to address whatever concerns the assembly wished, and contained only the most limited suggestions about appropriate general themes. In his letter of convocation the King called on his "faithful subjects to help us overcome all the difficulties in which we now find ourselves in regard to our finances", which certainly suggested, in a very general way, what he and some of his top advisors hoped for from the Estates General. But anyone who might have wondered about the prudence of raising other issues could note that the King also expressed the hope "that abuses of any kind be reformed", and that he promised his subjects "to listen favorably to their advice on everything that might concern the well-being of our peoples". ${ }^{22}$ Many high-level cabiers, moreover, reflect defiance of the King's expressed disapproval of "binding mandates", as we explain below.

The assemblies certainly found in one aspect of state finances a favorite topic: many of the most common demands in the cabiers of the nobility, third estate, and parishes alike, concern taxation. ${ }^{23}$ But the assemblies also made use of the considerable latitude provided in what subjects they might address. In designing our code, we found we needed to distinguish over $\mathrm{I}, 000$ institutions under discussion in the cabiers collectively.

19. Shapiro and Markoff, Revolutionary Demands, pp. 369-376.

20. Jean-Claude de Beugnot, Mémoires du Comte Bengnot, I779-I8I5 (Paris, 1959), p. 94.

21. Shapiro and Markoff, Revolutionary Demands, pp. I50-I55.

22. Jacques Cadart, "Lettre du Roi pour la convocation des Etats Généraux à Versailles le 26 avril 1789 ”, in idem, Le régime électoral, pp. 202-203.

23. Shapiro and Markoff, Revolutionary Demands, pp. 380-38I. 


\section{The role of the petition-bearer}

Third, the role of the petition-bearer has, in the history of petitions, been subject to great variation. Petition-bearers might be limited to delivering the document into the hands of the authority. If so, they are clearly replaceable by modern, effective postal systems. Petition-bearing might itself become a form of political action, and this action might vary in the degree to which it is improvised or ritualized. If the bearers become numerous, march from one location to another, assemble to hear speeches, carry signs, and chant slogans, we have, no doubt, an origin of the demonstration as a form of social action, which, eventually, can even do without the petition.

In the case of the cabiers, the role of their bearers was the occasion of considerable disagreement at the time. As we have seen, that role was embedded within the convocation of the Estates General. Deputies chosen by lower-level assemblies carried cabiers to higher ones; at the highest levels, deputies of the three orders carried cabiers to the Estates General where, had the standard model been followed, three ultimate cabiers, one from each order, would have been produced. (This last step was shortcircuited in the revolutionary crisis of 1789 .)

In the monarchy's crisis, a significant debate took place over the relationship between the deputy and the cabier. That debate pitted against one another two rival conceptions of the Estates General's purposes and activities, rival conceptions of who or what was to be represented at the Estates General, and in consequence rival conceptions of the purposes of the cabiers. We will present some evidence below that the assemblies who wrote the cabiers took different positions on this cluster of issues.

In the first view, what was to be represented were the corporate bodies out of which a society was constructed: its towns and villages, its provinces, its urban guilds, its nobility, its clergy. The cabier was where the views of such a group were recorded. The job of a deputy was:

(a) to carry that cabier to some higher body;

(b) to join with fellow deputies in collating the various cabiers that body received into a summary super-cabier; and

(c) to join with fellow deputies in choosing those who would carry that super-cabier further up the hierarchy.

At the end of this process lay the Estates General itself, which would aggregate the cabiers its members bore with them and present the ultimate compendium to the King. The King would study this material to know the state of his subjects, and their advice, but the decision rested with him. In this conception, a deputy, even at the pinnacle, the Estates General, is not a legislator, engaging in horse-trading with his fellow deputies and joining them in collectively hammering out bargains with the King. He is a 
conduit by which the views of those below arrive at the ear of the sole legislator, the King of France. This entire conception was an extremely idealized reading of the history of Estates General past; such Estates General in fact were sometimes able to bargain with kings, and, indeed, a main reason for calling them, as in the crisis of the late 1780 s, was that the royal government found that it needed someone with whom to strike a bargain. ${ }^{24}$

Embedded in this first conception of the deputy, the Estates General, and their relationship to the King was the conception of the cabier as a binding mandate. ${ }^{25}$ The cabier bound the deputy to advocate the demands it contained. The monarchy might like such a conception, to the extent that it inhibited the possibility of an Estates General striking out in some unexpected direction. And constituents might favor such a notion in a world without any way to monitor the behavior of their delegates afar, with no newspapers reporting deputies' positions, no future elections to lead a deputy to fear antagonizing constituents, and no organized parties imposing discipline. To the extent, moreover, that constituents saw the King as an opponent, they might favor mandates, not so much in order to bind the deputies as to give them leverage in dealing with the King. Those cabiers that enjoin the deputies to accept no new taxes without a constitution utilize just such a strategy.

Aspects of this first conception of a cabier were embodied in the royal convocation order:

(I) Describing deputies primarily as carriers of cabiers to a higher assembly, as, for example referring to the "deputies who shall be chosen by the rural parishes and communities in order to carry their cabiers". ${ }^{26}$

(2) Describing a higher assembly as engaged in "the amalgamation of the cabiers of the towns and communities into a single one", ${ }^{27}$ rather than as engaged in making a collective decision to forge a new document.

But a further view of the role of the deputy was also under consideration as the Estates General of 1789 was being planned. In this view, society is made up of a collection of individuals who were to be represented. No person had a right to be a deputy by virtue of rank or office; a deputy had to be chosen by some constituency. Wisdom was to be found in debate among individuals and in assemblies, and an Estates General was a place

24. The delegates to the Estates General of $\mathrm{I}_{4} 84$ were clearly engaged in independent bargaining with the monarch, and show few signs of restraint by their constituencies. See James Russell Major, Representative Institutions in Renaissance France, I42I-I559 (Madison, WI, 1960), pp. 64-7I.

25. We use the term "binding mandate" for what Hyslop calls an "imperative mandate."

26. Cadart, "Règlement", art. 31, p. 198.

27. Ibid., art. 34, p. 199 . 
for reasoned debate, a place in which distinguished delegates could reflect on the debate thus far and advance the national discussion. Since wisdom emerged from a process of dialogue, deputies were not to be bound by those who chose them. In such a conception, the hierarchy of assemblies might refine and improve upon the views submitted to them, not merely summarize them and collate them for transmission upwards. An Estates General was a protolegislature, engaged, in the last analysis, in a redefinition of the constitution of France. And such an Estates General would most certainly bargain with the King, especially about the scope of its own authority. In this conception, a cabier could not be a simple mandate, because deputies had to be able to horse-trade, to innovate, and to do more in dealing with royal authority than to pass on the views of those down below. But the monarchy, too, might favor such a conception, to the extent that binding mandates might seem a way to stiffen resistance to royal initiatives.

This view, too, found its way into how the convocation was framed by the King. In stressing that he will not "interfere, in any way, with the freedom of their deliberations", something beyond merely summarizing the views of those down below is acknowledged; and in committing himself to carrying out "what shall have been worked out in concert between us and the said Estates", he implies negotiations. ${ }^{28}$

While some were advocating what they believed to be the traditional conception, others, like Dauphinés Mounier, opposed any constraint on the freedom of action of the representatives of the people, and rejected mandates. And, if the cabiers were not mandates, why, he reasoned, have them at all? Sieyès urged what amounted to a compromise position: cabiers without mandates. ${ }^{29}$ This was the view adopted by the King, and strongly insisted upon in the basic convocation regulation: "His Majesty is persuaded that the confidence appropriate to an assembly that represents the entire nation forbids giving the deputies any instruction that could halt or trouble the course of deliberations." 30 Thus, in one of the many ways competing conceptions of the Estates General were embodied in the rules of 1789 , the King expressed disapproval of mandates, which, for some, were virtually synonymous with the cabiers, while retaining the cabier itself. And, as one of the many signs that assemblies thought things through for themselves, quite a number of them ignored the royal disapproval and restrained their deputies with a binding mandate. As we elaborate below, this was especially pronounced among the nobility: drawing on information provided by Beatrice Hyslop, by our count we

28. Ibid., p. 193; Cadart, "Lettre du Roi”, p. 203.

29. Philippe Sagnac, "Les cahiers de 1789 et leur valeur", Revne d'histoire moderne et contemporaine, 8 (1907), pp. 329-349.

30. Cadart, "Règlement", p. 193. 
can say that about three-quarters of the nobles' documents carried binding mandates, about two-fifths of the third estate's did, and about one-third of the clergy's. ${ }^{3}$

Mounier, Sieyès, and the King no doubt, rejected mandates because they expected that, in the lineup of forces in the crisis, binding the deputies would have been a barrier to the innovations in finance and taxation required to meet the monarchy's fiscal crisis. At the height of the crisis of June, when the King ordered the privileged estates to join with the third in a common assembly, a large number of nobles held that this would violate their mandates and, in response to the King's orders, returned to their constituencies for new instructions. While most of those who sought new powers did so in the first half of July, a good number of noble or clerical deputies attempted to meet separately for some weeks, but most eventually joined in the common meeting. A few of the more recalcitrant were seeking new powers from their constituents as late as the fall, keeping alive the notion that a deputy was an agent of those who elected him. ${ }^{32}$

Since the question of mandates would not only have a significant impact on how the new National Assembly went about its business but also on whether there would be any business at all on which it would be able to make binding decisions, the mandates were among the very first topics of its debates, virtually from the moment, in late June, 1789 , that deputies claimed they were a National Assembly. Harriet Applewhite's study of the positions of those deputies who spoke to that question in the early summer of 1789 shows that: "Mandates, one of the earliest substantive questions before the National Assembly, divided the embryonic left from the embryonic right". ${ }^{33}$ Those opposing binding mandates were later found on the left, those in support on the right, and those favoring the eventually winning compromise of having deputies with mandates seek new powers took a variety of political paths down the line. Future revolutionary electoral procedures generally retained assemblies, rather than isolating individual electors to cast votes in secret, ${ }^{34}$ but such discussions as might take place were not, as a matter of law, to bind the deputies, a point clearly stressed in the constitution of $179 \mathrm{I}$ : "The representatives named in the departments shall not be representatives of an individual department but of the entire Nation, and they may be given no mandate". As if for someone

\footnotetext{
3I. See note 46.

32. Timothy Tackett, Becoming a Revolutionary: The Deputies of the French National Assembly and the Emergence of a Revolutionary Culture (1789-1790) (Princeton, NJ, I996), pp. I I I-I65; Hyslop, Guide, pp. гог-102.

33. Harriet B. Applewhite, "Citizenship and Political Alignment in the National Assembly", in Renée Waldinger, Philip Dawson, and Isser Woloch (eds), The French Revolution and the Meaning of Citizenship (Westport, CT, 1993), pp. 43-58, 45.

34. Patrice Gueniffey, "Revolutionary Democracy and the Elections", in ibid., pp. 89-103.
} 
who might have missed the point, the next article begins: "The functions of primary and electoral assemblies are limited to electing". 35

\section{HOW TO READ THE CAHIERS}

Following the historians' classic injunction to engage in "criticism of sources", a good deal of ink has been expended on what sorts of information can be reliably mined from the cabiers. At various points historians have debated whether the cabiers are a source of "objective", factual information or are limited to the realm of the "subjective", the wishes and hopes of those who wrote them. An even longer discussion has been carried on about the "sincerity" or "authenticity" of the views expressed in either particular documents, particular kinds of cabiers, or even in the cabiers as a whole. If a village assembly was presided over by the local seigneurial judge (a likely possibility under the official rules), could their document be held an authentic expression of the community's views? If the community enlisted the advice or even the pen of a local priest or local attorney? If the document showed evidence that one or several locally circulating "model cabiers" had been read and some of its (or their) suggestions followed? While we agree that all such aspects of the context of cabier-writing are important to study, we believe that a great deal of this criticism suffers from an inadequate understanding of what sort of documents these texts are, an understanding that is essential to their proper interpretation as historical sources. Many criticisms derive, we think, from a notion that individual opinions are both the essential building blocks of historical processes, and the entities that are knowable through proper document study. The cabiers are not however some sort of X-ray into the hidden soul of French peasants, French clergy or French nobles. They are doubly public documents.

They are statements of collectivities. They were arrived at as the decision of some group of people, whether villagers, urban professionals, clergy, or nobles. They are statements that required an assembly's assent (but not necessarily, as the record makes abundantly clear, its unanimous assent to each and every statement). They, therefore, are inevitably the product of horse-trading, of deliberate omission of the concerns of some participants in the interests of securing the agreement of others, of debate in which we may be confident that the voice of some was weightier than the voice of others. The cabiers are not an aggregate of individual voices. They are a collective political act. This may be readily verified by observing that higher-level cabiers are not mere compendia of the lower-level cabiers, as

35. “Constitution du 3 Septembre, I79I", in Maurice Duverger, Constitutions et documents politiques, 2nd edn, (Paris, I960), p. Iо. 
one idealized conception of the transmission of views from his subjects to the King would have had it.

They are addressed to higher bodies at a specific moment. The cabiers were not produced in an institutional vacuum. They were written in order to produce desired outcomes in the midst of a great crisis in which, for many, change seemed possible, and from which, therefore, there was much to hope and much to fear. Assemblies had to consider what sorts of articles in a cabier would help bring about desired change and ward off undesired change. This is by no means the same thing as a compendium of an assembly's deepest wishes. Moreover, they were written in a time and place in which freedom to speak out was hardly a national tradition, and in a moment of crisis in which the group in command of force tomorrow was a matter of considerable uncertainty. If we impute even a minimal level of rationality to participants in those assemblies, we may be confident that considerations of prudence and of effectiveness played a significant part in what was put into the documents. One third-estate deputy later recalled the moderation he and his associates felt they had to display in their cabiers: "It was necessary to be cautious so as not to frighten despotism too much". ${ }^{36}$

The cabiers, then, are strategic statements of collectivities. They are not to be confused with what peasants or nobles said to their fellows at those meetings, but shrewdly omitted from the documents. To insist on some point might hopelessly divide the assembly, or to make another point might be impolitic, or ineffective. In many cases, it is possible that whatever peasants or nobles said to themselves, they would not even say to their fellows. ${ }^{37}$ Let us consider two concrete examples.

\section{Peasant reticence on food prices}

The parish cabiers usually make no mention of the soaring price of food. $3^{8}$ It is inconceivable that this shows a lack of interest in France's villages. Skyrocketing grain prices, caused by a catastrophically poor harvest, have been amply documented by historians, and sometimes even been held to be the critical trigger of revolution. ${ }^{39}$ Not only did France have a long

36. Quoted in Timothy Tackett, "Nobles and Third Estate in the Revolutionary Dynamic of the National Assembly, 1789-1790", American Historical Review, 94 (1989), pp. 27I-30I. Quotation on p. 276.

37. Very helpful in thinking about such matters: James C. Scott, Weapons of the Weak: Everyday Forms of Peasant Resistance (New Haven, CT [etc.], 1985).

38. Shapiro and Markoff, Revolutionary Demands, p. 424. In fact, only ir.4 per cent of the parish documents complain about the supply or price of any articles of consumption, and less than I per cent about food.

39. Camille-Ernest Labrousse, La crise de l'économie française à la fin de l'Ancien Régime et au début de la Révolution (Paris, 1944). 
tradition of popular mobilization in times of scarcity, with extensive rural involvement, but during the very weeks when the cabiers were being written, these kinds of popular actions constituted the major form of rural mobilization..$^{\circ}$ So why do the villagers who wrote the cabiers not address more often than they do the fear of hunger that was such a frequent catalyst to collective action? We conjecture that this was a rather divisive matter within village communities, where some families had enough land to produce a marketable surplus and others did not. Avoiding the subject, and indeed avoiding many other subjects that divided a village's haves and have-nots, ${ }^{4 \mathrm{I}}$ may have been a political decision to produce a more consensual cabier. As it happens cabiers that take up subjects that were likely to be contentious within rural communities ${ }^{42}$ tend to be from regions whose peasants engage in none of the many forms of mobilization found in the spring and summer of 1789 . The connecting thread that links a cabier addressing such topics and the absence of collective action may well be the lower level of village unity.

\section{Noble reticence on seigneurial rights}

More than one-fifth of the noble cabiers have not a word to say about seigneurial rights. ${ }^{43}$ Among those noble cabiers that do take up the seigneurial regime, there are considerably fewer grievances on that subject than found in the cabiers of the third estate (on the average 5.5 vs. 17.4). Seigneurial rights were a source of income and of pride for many lords. In light of the multifaceted critique of those rights from champions of monarchical power, economic development, peasant wellbeing, and judicial reform, under discussion for some time and now being incorporated into many third-estate cabiers, it is inconceivable that the one-fifth of noble assemblies who remain silent simply had other things on their minds. But unity may have been difficult to achieve: examining those noble cabiers that do treat the seigneurial regime, we have found that this is actually one of the subjects on which those nobles who express themselves disagree most with each other. ${ }^{44}$ We would expect such intranobility division to inhibit saying very much in their cabiers. Not only that, but the

40. Cynthia Bouton, "Les mouvements de subsistence et le problème de l'économie morale sous l'Ancien Régime et la Révolution française", Annales historiques de la Révolution française, 3 I 9 (2000), pp. 7I-100; John Markoff, The Abolition of Feudalism: Peasants, Lords, and Legislators in the French Revolution (University Park, PA, 1996), p. 287.

4I. Shapiro and Markoff, Revolutionary Demands, pp. 424-426.

42. Besides agricultural prices, these include communal rights, which divided those who benefited from those whose livelihoods were injured by them, and the auction agents whose sales of the meager possessions of the bankrupt were opportunities for the better off.

43. Markoff, Abolition of Feudalism, p. 4I.

44. Shapiro and Markoff, Revolutionary Demands, pp. 288-289. 
nobles, meeting in the same town at the same time as the third estate, were likely to be keenly aware of their inability to frame a defense in terms that would generate much assent from anyone. The prudent course may well have been to say as little as possible, or even nothing at all. The nobility is, in fact, far more likely to dare urge that a particular seigneurial right be maintained if the third estate has relatively little to say about it. In more precise statistical terms: if we consider the dozen specific seigneurial rights most discussed in the noble cabiers, there is a negative correlation between the proportion of noble cabiers demanding that the right be maintained and the proportion of third-estate cabiers that discuss that particular right, a substantial $0.69 .4^{45}$ So noble assemblies, we suggest, acted with a calculated prudence: if the third estate was particularly focused on some specific right, this was not the right to try to defend; and some assemblies opted to say nothing at all.

\section{Cabiers as collective and strategic}

All this implies that an understanding of these documents, and their contents, demands something very different than any assumption that we are looking for the aggregated wishes of independent, isolated individuals. The crafting of cabiers was embedded in social relationships. The cabiers, therefore, are to be understood as collective and as strategic. Searches for the authentic individual or the sincere voice of the heart are as inappropriate as they would be if we were looking at the platforms of contemporary political parties. Even that countermodel, the modern public-opinion poll, in fact produces statements that are embedded in social relationships and in which strategic speech plays a role. Publicopinion professionals are keenly aware, as a major methodological problem, of the degree to which respondents give systematically different answers to men and women interviewers, young and old, those well dressed and those in casual attire, and so forth, because human beings cannot help attempting to create impressions and wish for different impressions on members of different categories. What makes this a problem, rather than a fascinating object of research in its own right is that we are trying to find that pristine, uncontaminated, sincere, individual opinion - which does not exist.

\section{BINDING MANDATES}

In judging the character of the cabiers de doléances of 1789 as petitions, and their proper uses in research on the Revolution, the prevalence and the 
Table I. Noble mandates by third estate mandates from the same bailliage

\begin{tabular}{lccc}
\hline Noble mandate & \multicolumn{2}{c}{ Third estate mandate } & Total \\
\cline { 2 - 3 } & Absent & Present & \\
\hline Absent & $29.35 \%$ & $17.19 \%$ & $24.36 \%$ \\
Present & $70.65 \%$ & $82.81 \%$ & $75.64 \%$ \\
No. of cases & 92 & 64 & 156 \\
& $100.00 \%$ & $100.00 \%$ & $100.00 \%$ \\
\hline
\end{tabular}

Chi-Square $=3.029 \mathrm{I}$

$\mathrm{P}=0.082$

meaning of the binding mandates are of major significance. Their study can tell us to what extent these documents were regarded as constraints upon the actions of elected deputies, and to what extent they were provided as guidance to a modern representative, elected to make decisions and bargains in the interests of his constituents. We turn first to the simple question of how many assemblies passed mandates. Of the noble assemblies whose cabiers are available, 74 per cent did so, as did 4I per cent of the third-estate assemblies, and only 3 I per cent of the assemblies of the clergy. ${ }^{6}$ While the predominance of nobles would seem to support the common notion of the mandate as a means of resistance to change on the part of the privileged orders, the fact that a greater number of thirdestate assemblies passed mandates than did assemblies of the clergy seems to require a different interpretation. One hypothesis might be that the clergy were reluctant to put controls on their superiors in the church hierarchy, but we find that the proportion of assemblies issuing mandates is no different where their deputies are members of the upper clergy than when they are not.

\section{The geography of mandates}

While there is some slight tendency for any estate to be more likely to pass a binding mandate if another estate of the same bailliage does so, in no case does this relationship reach the 5-per-cent level of significance by the ChiSquare test. The strongest of these weak relationships is between the third estate and the nobles, which is presented in Table $\mathrm{I}$.

Despite the weakness of this relationship, it does appear that the binding

46. Hyslop, Guide, pp. 47 I-473. Our proportions differ from Hyslop's because we include only cases with extant cabiers, lacking which one cannot be sure whether there was a binding mandate or not, since the mandate might sometimes be given in the cabier itself rather than in a separate document. 


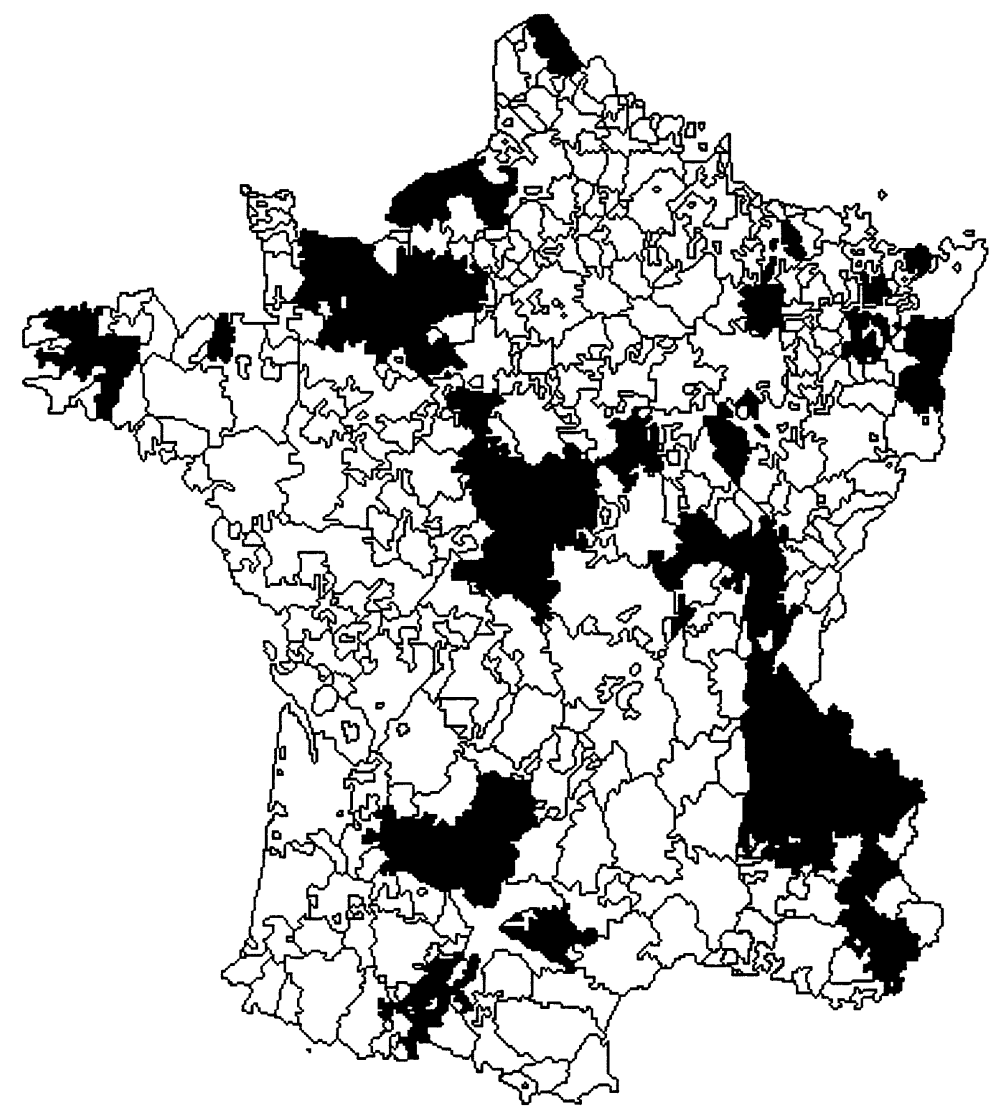

Figure I. Clerical mandates (Dark areas have mandates.)

mandates come from definite restricted geographic regions. The similarity of the geographic distributions shown in Figures $\mathrm{I}$ to 3 is striking, indicating that while there is only slight, if any, tendency of mandates of different estates to come from the same bailliages, they do seem to frequently come from the same regions.

\section{Mandates and committees of correspondence}

Beatrice Hyslop summarizes the variety of purposes that led assemblies to form committees of correspondence: "a desire to keep tab on the deputies, to furnish the deputy with supplementary information about the bailliage, to perpetuate the electoral assembly, and to secure a method of receiving information from the deputies which could be relayed to the constitu- 


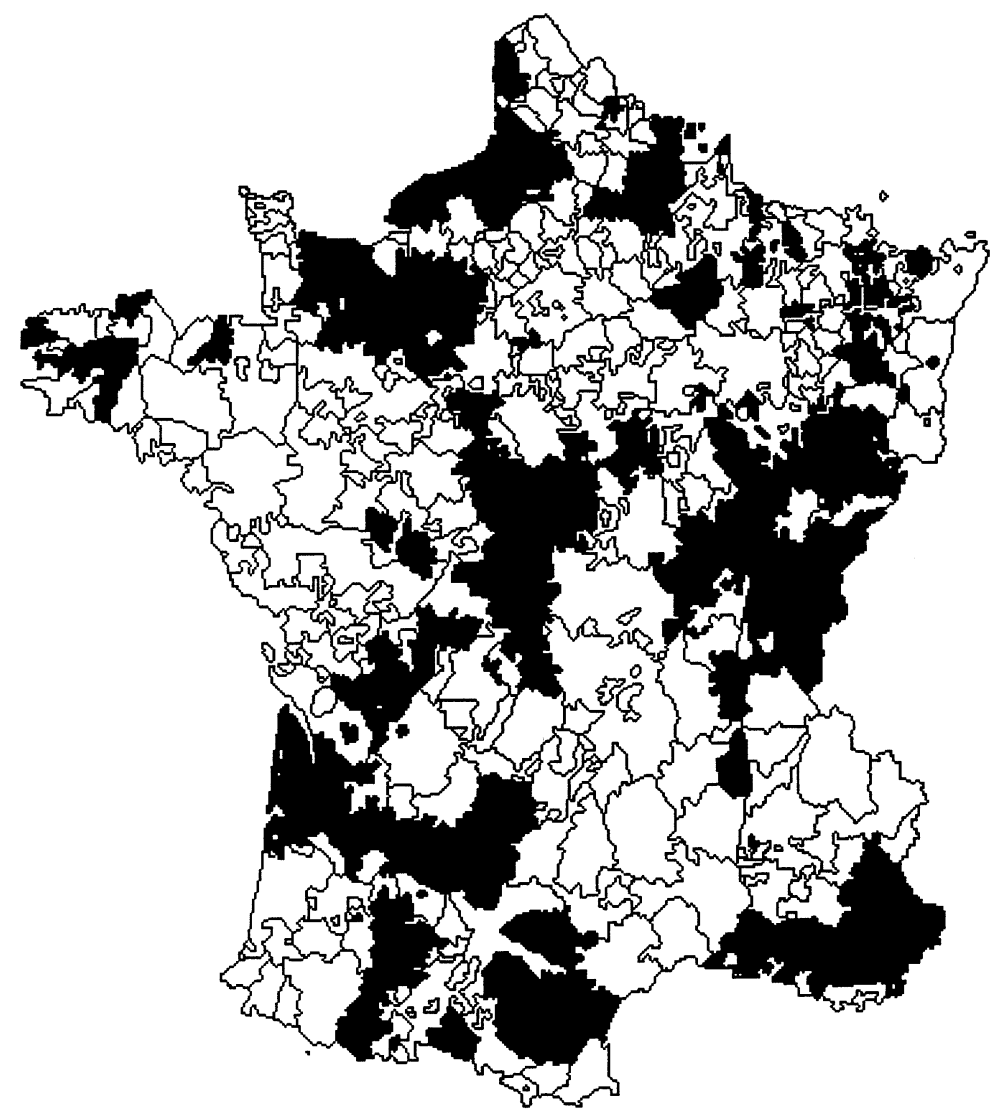

Figure 2. Noble mandates (Dark areas have mandates.)

ents". ${ }^{47}$ Insofar as these committees were designed to restrain, and not merely to inform the deputies, it is not surprising that, where they were established, the assemblies also frequently wrote mandates for the same purpose. There is a very strong relationship between the presence of a binding mandate and the establishment of a committee of correspondence in a bailliage. This relationship is well beyond the I-per-cent level of confidence in all three estates.

In fact, the establishment of such a committee went a step beyond a mandate as a means by which the assembly could control the deputy; it was a mechanism by which, faced later with a new, unanticipated situation, he could be given new instructions. 


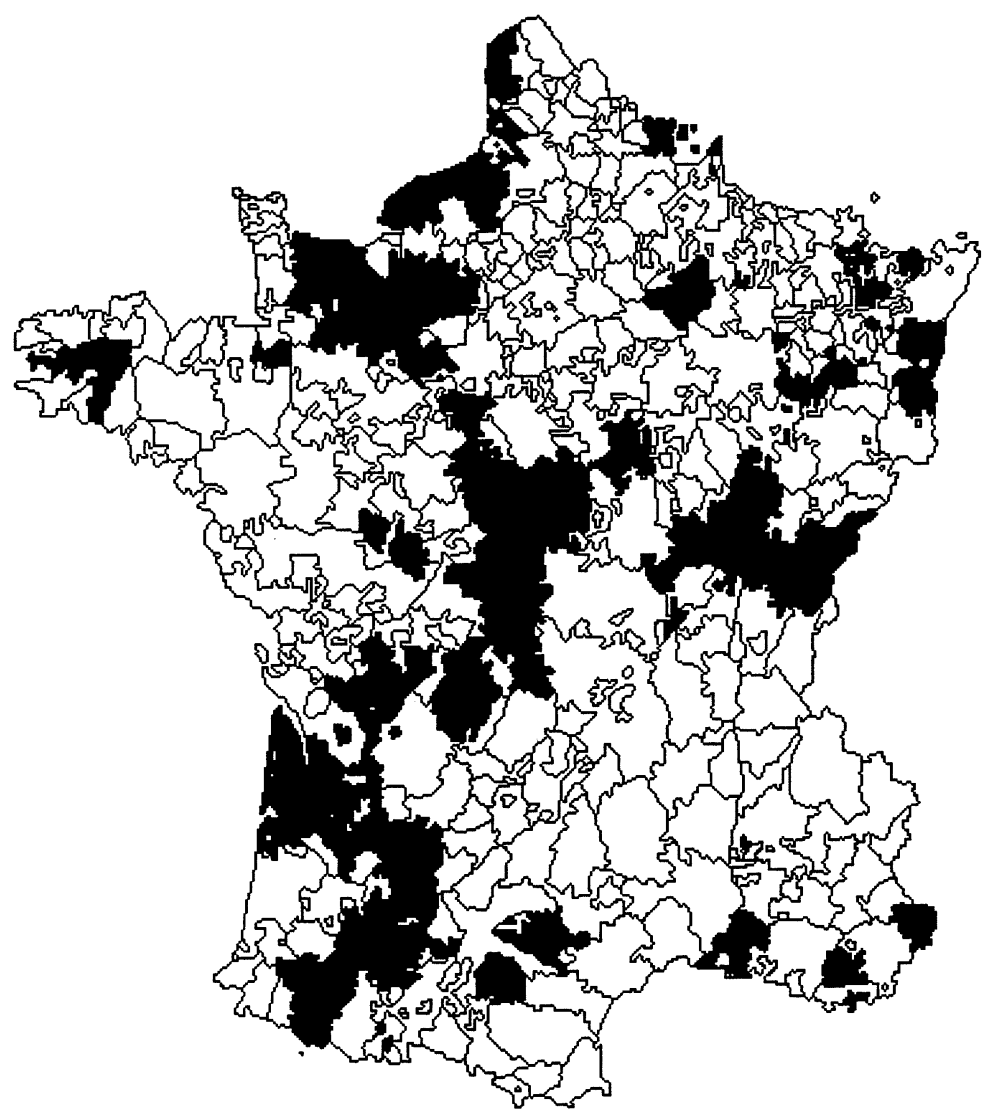

Figure 3. Third-estate mandates (Dark areas have mandates.)

\section{Mandates and voting in the Estates General}

The literature on the French Revolution concentrates on the role of the mandates in the crisis of June 1789 . After the failure of the government to coerce the third estate into acknowledging three independent estates, with separate deliberations and vote by estate, the King gave in to the demand of the commoners to recognize them as a National Constituent Assembly, and ordered the clergy and nobility to join with the third. At this time, a large number of noble deputies claimed their inability to obey such an order because of their mandates, and the King ordered them to return to their constituencies for new instructions. Because of these dramatic events, many narratives of the Revolutionary period either describe the mandates 
Table 2. Committee of correspondence established by the clergy, by binding mandate

\begin{tabular}{lccc}
\hline Binding mandate & \multicolumn{2}{c}{ Clergy: committee of correspondence } & \multirow{2}{*}{ Total } \\
\cline { 2 - 3 } & Not formed & Formed & \\
\hline Absent & $77.03 \%$ & $5.56 \%$ & $69.28 \%$ \\
Present & $22.97 \%$ & $94.44 \%$ & $30.72 \%$ \\
No. of cases & 148 & 18 & 166 \\
& $100.00 \%$ & $100.00 \%$ & $100.00 \%$ \\
\hline
\end{tabular}

Chi-Square $=38.5159$

$\mathrm{P}=0.000$

Table 3. Committee of correspondence established by the nobility, by binding mandate

\begin{tabular}{lccc}
\hline Binding mandate & \multicolumn{2}{c}{ Nobility: committee of correspondence } & \multirow{2}{*}{ Total } \\
\cline { 2 - 3 } & Not formed & Formed & \\
\hline Absent & $30.88 \%$ & $3.33 \%$ & $25.90 \%$ \\
Present & $69.12 \%$ & $96.67 \%$ & $74.10 \%$ \\
No. of cases & 136 & 30 & 166 \\
& $100.00 \%$ & $100.00 \%$ & $100.00 \%$ \\
\hline
\end{tabular}

Chi-Square $=9.7187$

$\mathrm{P}=0.002$

Table 4. Committee of correspondence established by the third estate, by binding mandate

\begin{tabular}{lccc}
\hline Binding mandate & \multicolumn{2}{c}{ Third estate: committee of correspondence } & \multirow{2}{*}{ Total } \\
\cline { 2 - 3 } & Not formed & Formed & \\
\hline Absent & $68.71 \%$ & $11.76 \%$ & $58.88 \%$ \\
Present & $31.29 \%$ & $88.24 \%$ & $41.12 \%$ \\
No. of cases & 163 & 34 & 197 \\
& $100.00 \%$ & $100.00 \%$ & $100.00 \%$ \\
\hline
\end{tabular}

Chi-Square $=37.68 \mathrm{I} 7$

$\mathrm{P}=0.000$

as restricted to the issue of vote by head or estate, or mention the mandates only in connection with this conflict, leaving the impression that they were concerned only with this issue.

Our examination of mandates does not confim this impression. We find some mandates applying to an entire cabier, containing dozens or even 
hundreds of grievances on different subjects. In other cases, the mandate applies to a group of grievances particularly selected, which may or may not contain the issue of vote by head or by order. By way of illustrating a bit of this variety we note a few examples.

The third estate of Charolles, having taken a firm stand in favor "of a constitution that does not permit the establishment of any law without the authorization of the prince and the consent of the representatives of the people" goes on to "forbid [...] their deputies to vote on any matter before such a constitution is granted", and declares "that they will withdraw all their powers should they contravene the above mandate"..$^{8}$

The nobility of Agen present some sixteen items on which their deputies are not to deviate under any circumstances, while allowing them to concede some ground on others if after a good fight they see they will lose. With regard to the mandated sixteen items: "Our intention is to limit the powers that our deputies receive from us in regard to the matters just set forth [...]. We disavow them in advance, should they be guilty of not fulfilling their undertakings to strict obedience to our will, without in anyway adding, deleting or modifying." With regard to the remainder of the cabier, however,

We have too much confidence in them and believe them too enlightened not to leave them in complete freedom with regard to the following articles. We do urge them, upon their honor, to formally insist upon each of the demands that are going to be expressed - and not to abandon any unless the general sentiment makes it impossible to resist longer.

(Apparently not quite willing to simply trust the good judgment of their deputies, the assembly added a nuanced discussion spelling out circumstances in which the deputies will be permitted to back down from an insistence on vote by order.) ${ }^{49}$ This is in considerable contrast to the nobility of Aix, who give their deputies instructions but "leave to their conscience to decide on all matters according to their patriotism and their honor, giving them full and sufficient power to propose, remonstrate, advise and consent". ${ }^{\circ}$

Thus, the scope of mandates is highly varied, as are the subjects covered under them. In fact, it is not even true that noble mandates are significantly more common when there is a demand for vote by order, or that third-estate mandates are significantly more common when assemblies demanded vote by head. (See Tables 5 and 6.)

While both tables show tendencies in the conventionally expected

48. J. Mavidal and E. Laurent, Archives parlementaires de I787 à I 860 (première série) (Paris, I879), vol. 2, p. 619.

49. Ibid., vol. I, pp. 680-68 I.

50. Ibid., p. 693. 
Table 5. Binding mandates by vote by order, noble cahiers

\begin{tabular}{lccc}
\hline Binding mandate & \multicolumn{2}{c}{ Noble cabiers demands for vote by order } & Total \\
\cline { 2 - 3 } & Absent & Present & \\
\hline Absent & $32.35 \%$ & $21.43 \%$ & $25.90 \%$ \\
Present & $67.65 \%$ & $78.57 \%$ & $74.10 \%$ \\
No. of cases & 68 & 98 & 166 \\
& $100.00 \%$ & $100.00 \%$ & $100.00 \%$ \\
\hline
\end{tabular}

Chi-Square $=2.496 \mathrm{I}$

$\mathrm{P}=0 . \mathrm{II} 4$

Table 6. Binding mandates by vote by head, third-estate cahiers

\begin{tabular}{lccc}
\hline Binding mandate & \multicolumn{2}{c}{ Third-estate cabiers demands for vote by head } & \multirow{2}{*}{ Total } \\
\cline { 2 - 2 } & Absent & Present & \\
\cline { 2 - 3 } & $71.43 \%$ & $56.17 \%$ & $58.88 \%$ \\
Absent & $28.57 \%$ & $43.83 \%$ & $41.12 \%$ \\
Present & 35 & 162 & 197 \\
No. of cases & $100.00 \%$ & $100.00 \%$ & $100.00 \%$ \\
& & &
\end{tabular}

Chi-Square $=2.7668$

$\mathrm{P}=0.096$

direction, in neither case does the relationship attain the 5-per-cent level of significance which would leave us with some confidence that it is more than a chance occurrence.

\section{Mandates and the ideology of the cahiers}

One might suppose that those noble assemblies that were especially conservative would have utilized mandates to reinforce this position and that third-estate assemblies that were especially radical would have done the same. But it is also not the case that noble mandates are associated with cabiers which are notably conservative, or that third-estate mandates are to be found in bailliages with especially radical views. We may take the proportion of all actions that call for an institution to be maintained as a general indicator of conservatism and the proportion calling for outright abolition as a general indicator of radicalism. Tables 7-10 show the mean frequency with which noble and third-estate cabiers call for actions (on any subject) entailing the abolition of social institutions, or their maintenance.

While Table 7 shows a slightly greater conservative tendency among the 
Table 7. Mean number of grievances to "abolish" institutions in the noble cahiers, by presence of binding mandates

\begin{tabular}{lccc}
\hline Binding mandates & \multicolumn{2}{c}{ Noble cabiers: no. of grievances to “abolish” } & Frequency \\
\cline { 2 - 3 } & \multicolumn{1}{c}{ Mean } & Std. Dev. & \\
\hline Absent & 0.11076047 & 0.06008692 & 43 \\
Present & 0.0956626 & 0.04479788 & 123 \\
Total & 0.09957349 & 0.04946605 & 166 \\
\hline
\end{tabular}

$\mathrm{t}=\mathrm{I} .73$ with $\mathrm{i} 64$ d.f.

$P>|t|=0.0849$

Table 8. Mean number of grievances to "maintain" institutions in the noble cahiers by presence of binding mandates

Binding mandates Noble cabiers: no. of grievances to “maintain” Frequency

\begin{tabular}{lllr} 
& Mean & Std. Dev. & \\
\hline Absent & 0.01808372 & 0.02620214 & 43 \\
Present & 0.01318049 & 0.01513846 & 123 \\
Total & 0.0144506 & 0.01867753 & 166 \\
\hline
\end{tabular}

$\mathrm{t}=\mathrm{I} .49$ with $\mathrm{I} 64$ d.f.

$\mathrm{P}>|\mathrm{t}|=0.1389$

Table 9. Mean number of grievances to "abolish" institutions in the thirdestate cahiers by presence of binding mandates

\begin{tabular}{lccr}
\hline Binding mandate & Third estate cabiers: no. of grievances to “abolish” & Frequency \\
\cline { 2 - 3 } & Mean & Std. Dev. & \\
\hline Absent & 0.14539483 & 0.05802291 & 116 \\
Present & 0.14552963 & 0.04713166 & 81 \\
Total & 0.14545025 & 0.05368455 & 197 \\
\hline
\end{tabular}

$\mathrm{t}=-0.02$ with 195 d.f.

$\mathrm{P}>|\mathrm{t}|=0.9862$

noble cabiers with mandates, it is not significant by the standard t-test criterion of 5-per-cent probability and, furthermore, this finding is not supported by Table 8 , where it actually appears that the noble cabiers without mandates are slightly more conservative than those with mandates, though the difference is not significant. Tables 9 and ro show no differences at all in conservatism or radicalism between third-estate cabiers with and without mandates. 
Table 1о. Mean number of grievances to "maintain" institutions in the third-estate cahiers by presence of binding mandates

\begin{tabular}{lccc}
\hline Binding mandate & $\begin{array}{c}\text { Third estate cabiers: mean no. of grievances to } \\
\text { "maintain" }\end{array}$ & Frequency \\
\cline { 2 - 3 } & Mean & Std. Dev. & \\
\hline Absent & 0.01108448 & 0.00933398 & 116 \\
Present & 0.01291728 & 0.01003254 & 81 \\
Total & 0.01183807 & 0.00964459 & 197 \\
\hline
\end{tabular}

$\mathrm{t}=-\mathrm{I} .3 \mathrm{I}$ with $\mathrm{I} 95$ d.f.

$P>|t|=0.190 I$

Table i. Demand for doubling the deputies of the third by binding mandate: third-estate assemblies

\begin{tabular}{lccc}
\hline Binding mandate & \multicolumn{2}{c}{ Double the third } & Total \\
\cline { 2 - 3 } & Absent & Present & \\
\hline Absent & $51.58 \%$ & $65.69 \%$ & $58.88 \%$ \\
Present & $48.42 \%$ & $34.31 \%$ & $41.12 \%$ \\
No. of cases & 95 & 102 & 197 \\
& $100.00 \%$ & $100.00 \%$ & $100.00 \%$ \\
\hline
\end{tabular}

Chi-Square $=4.0433$

$\mathrm{P}=0.044$

\section{Mandates and the organization of the Estates General}

Although the demand for vote by head is not significantly related to the presence of a mandate in the third estate, two closely related demands, also addressed to the organization of the Estates General, do have significant relationships. While the convocation regulations of 1789 provided for twice the number of deputies from the third estate as were authorized for either of the other two estates, there were frequent demands in the thirdestate cabiers for such an arrangement, presumably addressed to the longer term constitutional question of how the estates would be organized in the future. Table I I shows that, in the third estate, this demand is significantly more common where there are binding mandates. And many third-estate documents called for the permanence of the Estates General as an institution, or for regular meetings of the assembly, instead of the traditional arrangement whereby they met at the will of the monarch. Table i 2 shows a significant relationship between these demands in the third estate and the presence of a binding mandate. The nobles show no such relationships. 
Table I2. Mean number of demands for permanence or regular meetings of the Estates General in the third estate cahiers, by presence of binding mandates

\begin{tabular}{lccr}
\hline Binding mandates & \multicolumn{2}{c}{$\begin{array}{c}\text { Third estate cabiers: demands for } \\
\text { permanence for estates }\end{array}$} & Frequency \\
\cline { 2 - 3 } & Mean & Std. Dev. & \\
\hline Absent & 0.71551724 & 0.6158209 & 116 \\
Present & 0.91358025 & 0.77777778 & 81 \\
Total & 0.79695431 & 0.69207678 & 197 \\
\hline
\end{tabular}

$\mathrm{t}=-\mathrm{r} .99$ with $\mathrm{i} 95$ d.f.

$\mathrm{P}>|\mathrm{t}|=0.0478$

Table I 3. Mean number of demands that powers and functions be assigned to the Estates General in noble cahiers, by binding mandates

\begin{tabular}{|c|c|c|c|}
\hline \multirow[t]{2}{*}{ Binding mandates } & \multicolumn{2}{|c|}{ Number of demands } & \multirow[t]{2}{*}{ Frequency } \\
\hline & Mean & Std. Dev. & \\
\hline Absent & 2.9767442 & 2.6230514 & 43 \\
\hline Present & 4.0406504 & 2.6716434 & 123 \\
\hline Total & 3.7650602 & 2.692118 & 166 \\
\hline
\end{tabular}

$\mathrm{t}=-2.26$ with $\mathrm{I} 64$ d.f.

$\mathrm{P}>|\mathrm{t}|=0.025^{2}$

However, they do frequently insist upon specific powers and functions to be exercised by the Estates General, and these demands are significantly more frequent in bailliages with mandates, as shown in Table I 3 . The third estate shows no relationship.

If mandates are a clue, a part of the third estate is taking a firmer stand on the autonomy of the Estates General, while a part of the nobility digs in its heels about its precise powers. This amounts to a two-pronged assault on absolutism. For those who like to speculate on history's might-have-beens, this interesting datum points up how difficult it would have been for the monarchy to abort the crisis by successfully allying with either nobility or third estate against the other. But it also suggests that, in the spring of 1789 , the challenge posed by the third estate was more fundamental. Although some of France's aristocrats had long been at the center of struggles to maintain arenas of autonomy from monarchical control, it appears that, in the spring of 1789 , it was the commoners who were more intransigent over the establishment of a newly independent Estates General, the fundamental departure from absolutism. 


\section{CONCLUSION}

While the cabiers de doléances of 1789 are, as commonly believed, unique documents, we find it methodologically useful to regard them in a comparative framework as petitions, in some respects like other petitions in the early modern period. In particular, like all petitions, they must be understood in the light of the circumstances of their origin, the way in which they were produced, and the role of the petition bearer. In evaluating the last of these considerations, a detailed look at the mandates often passed by the assemblies helps to clarify France's struggles as it slid into revolution.

As French assemblies made their different decisions about whether to treat their deputies as free to negotiate on their behalf or as agents bound in detail to their expressed will, they anticipated some of the difficult tensions between mobilized citizens and elected representatives that was to characterize the entire revolutionary period. Was an election the device for choosing an assembly whose decisions would constitute the only occasion on which the voice of the sovereign people would be manifest? Or would an election be but one channel through which the people would speak, with other channels open through which the people could make clear that deputies were merely their agents? Was popular sovereignty to be identified with parliamentary sovereignty? Champions of popular sovereignty might make different stands at different moments - the Left might be sympathetic to pressures upon the national legislature from the mobilized sections of Paris and even claim a right to insurrection, for example, yet reject the notion that the ultimate decision on the fate of the King be taken out of the hands of the Convention and lodged in a national referendum.

If we may look beyond the French Revolutionary context and glance downstream over the next two centuries in which the institutions of contemporary democracy were forged, we may note a deep significance in this neglected and long-forgotten debate over the details of just what kind of petitions the cabiers de doléances were to be. In claiming that the right to rule could and should rest on popular will, late eighteenth-century revolutionaries opened up the question of precisely what were to be the institutions of the new democratic order, a question in no way settled by their general rejection of Athenian models (the assembled citizenry, the agent chosen by lot) and substitution of a scheme of representation. ${ }^{\text {I }}$ The question of whether a cabier was to be a binding mandate was one occasion on which the nature of that representation was fought out, and, along with

5. John Markoff, Waves of Democracy: Social Movements and Political Change (Thousand Oaks, CA, 1996), and "Where and When Was Democracy Invented?", Comparative Studies in Society and History, 4I (1999), pp. 660-690. 
it, the nature of the relationship between the democratically governed and those who claimed to govern democratically. The annulment of the mandates, and the subsequent abandonment of cabiers in French elections, were a piece of the multisided and multicontinental process by which democracy has come to be defined. But - for ill or good - not defined beyond question: the growth of state referenda in the United States today, ${ }^{52}$ and the development of popular consultative assemblies in Brazilian cities, ${ }^{53}$ are just two of the signs that the relationship of citizens and governors is again in question at the beginning of the twenty-first century. 